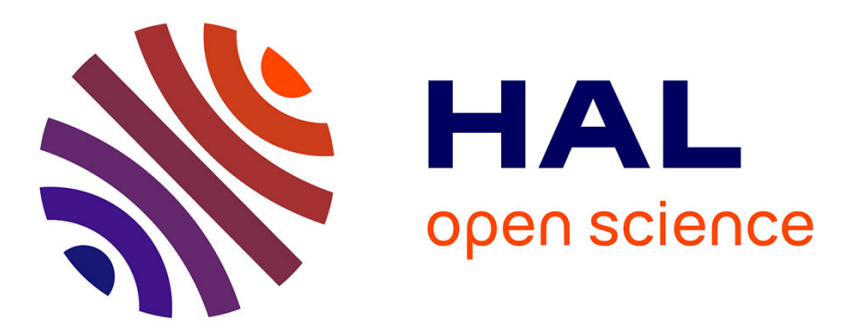

\title{
Inflammation and Inflammatory Diseases: How Our Language Influences Our Therapeutic Paradigms
}

\author{
Tanguy Chabrol, François R. Berger, Didier Wion
}

\section{To cite this version:}

Tanguy Chabrol, François R. Berger, Didier Wion. Inflammation and Inflammatory Diseases: How Our Language Influences Our Therapeutic Paradigms. BioEssays, 2018, 40 (9), pp.1800103. 10.1002/bies.201800103 . inserm-02478110

HAL Id: inserm-02478110 https://www.hal.inserm.fr/inserm-02478110

Submitted on 13 Feb 2020

HAL is a multi-disciplinary open access archive for the deposit and dissemination of scientific research documents, whether they are published or not. The documents may come from teaching and research institutions in France or abroad, or from public or private research centers.
L'archive ouverte pluridisciplinaire HAL, est destinée au dépôt et à la diffusion de documents scientifiques de niveau recherche, publiés ou non, émanant des établissements d'enseignement et de recherche français ou étrangers, des laboratoires publics ou privés. 


\section{Inflammation and Inflammatory Diseases: How Our Language Influences Our Therapeutic Paradigms}

Tanguy Chabrol, François Berger, and Didier Wion* INSERM UMR1205 BrainTech Lab Universite Grenoble Alpes La Tronche 38706, France

E-mail: didier.wion@univ-grenoble-alpes.fr

"Everything we perceive is influenced not only by what we have previously perceived, but also by what the society into which we are born has perceived and has formulated into language symbol."[1]

Inflammation plays a major role in many diseases including, atherosclerosis, neurodegenerative diseases, diabetes, and cancer.[2] Therefore, anti-inflammatory treatments are seen as a cornerstone of many therapies. When dealing with inflammation and anti-inflammatory therapies, we have to consider that the concept of inflammation has been shaped by the history of the term. The association of wounds with redness and heat, two symptoms of what would be later named inflammation, may have been first noticed by prehistoric humans. The concept of inflammation itself can be traced back to the hieroglyph of a flame on Egyptian papyrus (Figure 1A). [3] Our current word "inflammation" comes from the Latin "inflammatio," referring to "fire" and "flame." We also have in mind Celsus's definition of inflammation: "Notae vero inflammationis sunt quatuor: rubor et tumor cum calor et dolor" ("The signs of inflammation are fourfold: redness and swelling, with heat and pain"), in which three of the four distinctive signs have some connection to fire. However, "scientific objectivity is possible only if one has broken first the immediate object, if one has refused to yield to the seduction of the initial choice, if one has checked and contradicted the thoughts which arise from one's first observation."[4] The questioning of any medical term whose meaning stems from prescientific observations must be an integral part of our experimental process.[5] Inflammation provides an eloquent example of this.

Inflammation in its acute phase is "rubor, calor, and dolor." These are symptoms. They match the hieroglyph of the flaming brazier and the etymology of "inflammation" (Figure 1A). However, inflammation, in complement to its innate immune and antimicrobial functions, also plays a crucial role in the regeneration of tissues and wound repair.[6] In addition to its acute phase, inflammation also includes an active resolving phase that requires the production of resolving mediators including, among others, cytokines (IL-10, TGF- $\beta$ ), and specialized pro-resolving mediators (SPMs) (lipoxins, resolvins, maresins, protectins) (Figure 1A).[7,8] Importantly, SPMs do not compromise host immune competence.[8] The acute phase triggers the resolving one, and both phases largely overlap and interact instead of interfering (Figure $1 \mathrm{~A}$ ). Hence, anti-inflammatory drugs targeting acute inflammation can have paradoxical "resolution-toxic" side effects.[8] These two phases make the inflammatory process. In the absence of either the acute or the resolving phase, healing does not occur. In other words, the resolving phase is intrinsic to the physiology of inflammation, and non-resolving inflammation leads to the failure of the inflammatory process. The resolving phase is reparative inflammation-referred to in certain contexts as "cold inflammation."

Cold inflammation is an oxymoron. It has probably been estranged from the concept of inflammation by the semantic/ epistemological obstacle that the word "inflammation" conveys. In the words of Wittgenstein: "the limits of my language are the limits of my mind." 
However, here, these limits are transient. They can be overcome by inventing new words, symbols, or expression. The interactions between language and mind are bidirectional. Formulating a different clinical vocabulary for inflammation might be considered.

Deprived of its resolving phase, inflammation is no longer physiologic but pathologic; it remains incomplete. Consequently, a disease that impedes or desynchronizes the active resolving phase of inflammation jeopardizes healing. Such a disease is, semantically and physiologically speaking, "anti-inflammatory." Here is the paradox: non-resolved inflammation is genuinely "anti-inflammatory." What we name "chronic inflammation" is failed inflammation. Chronic inflammation is a symptom of an "anti-inflammatory" pathology. As regards the description of the diseases, it remains the same: the tissues are "inflamed." However, in some cases, such as in some degenerative diseases, the pathologic connection is no longer between acute or chronic inflammation and disease, but between incomplete or failed inflammation and disease. As regards cancer, cancer-related

inflammation is also a disrupted inflammation. Cancer associated inflammation is a symptom of an inflammatory dissonance. Inflammatory dissonance occurs when acute and resolving inflammation reinforce each other and triggers a vicious self-perpetuating circle. Tumors have been viewed as "wounds that do not heal."[9] Inflammatory dissonance generates a never-ending process of acute-reparative inflammation (i.e., chronic inflammation), that takes charge of tumor tissue regeneration/repair. Inflammatory dissonance places tumors into a perpetually regenerating state, and they never enter the scaring phase of inflammation. Regeneration is healing, and cancer tissue is in a state of continuous regeneration/healing. In cancer, it is the normal tissue that does not heal. Inflammation dissonance, not inflammation, is a hallmark of cancer. For all these reasons, anti inflammatory therapies will remain symptomatic as long as they do not ensure the proper activation of the resolving phase and its subsequent progression-i.e., toward tissue regeneration in the case of degenerative diseases and toward tissue scarring in the case of cancer. This small paradigm shift changes how we perceive the connection between inflammation and disease is, and what the appropriate therapy should be. Pro-resolving and anti-inflammatory therapies are fundamentally different.[8] When a connection exists between a physiological process (such as inflammation), and a disease (such a degenerative disease or cancer), the therapeutic options are either to restore the physiological function or to inhibit the pathophysiological process. We usually dub the first option "pro- ", and the second "anti-." The choice between "pro-" and "anti-" therapies would depend on whether the restoration of the physiological function is mandatory for patient recovery or not. If it is, we must foster "pro-therapies" because "anti-therapies" - even if they transiently suppress the symptoms - would probably fail to cure the disease.[5] The physiological endpoint of inflammation is the promotion of healing, not the destruction of cells or tissue. Therefore, the therapeutic goal is not to fight inflammation but to restore its physiological function. Therapies targeting the immune system, including anti-inflammatory and immunotherapies, will remain incomplete as long as they do not restore the integral physiological function of inflammation that includes the resolving phase. Suppressing symptoms, although

important for patient welfare, may not be sufficient to cure disease, and anti-inflammatory therapies will probably fail unless they are associated with pro-resolving therapies. In this context, resolvins and other members of the specialized proresolving mediator family have recently demonstrated their potential to resolve the inflammatory dissonance between the acute and resolving phases of inflammation without compromising host defenses. $[7,8,10]$ Symptoms and the words used to describe them are symbols. Therapeutic paradigms must 
reunify the semiology and the physiology of inflammation to restore the entirety of its function, otherwise treatments, truncated as they currently are, will continue to fail. The limits of our language have for too long been the limits of our therapeutic paradigms.
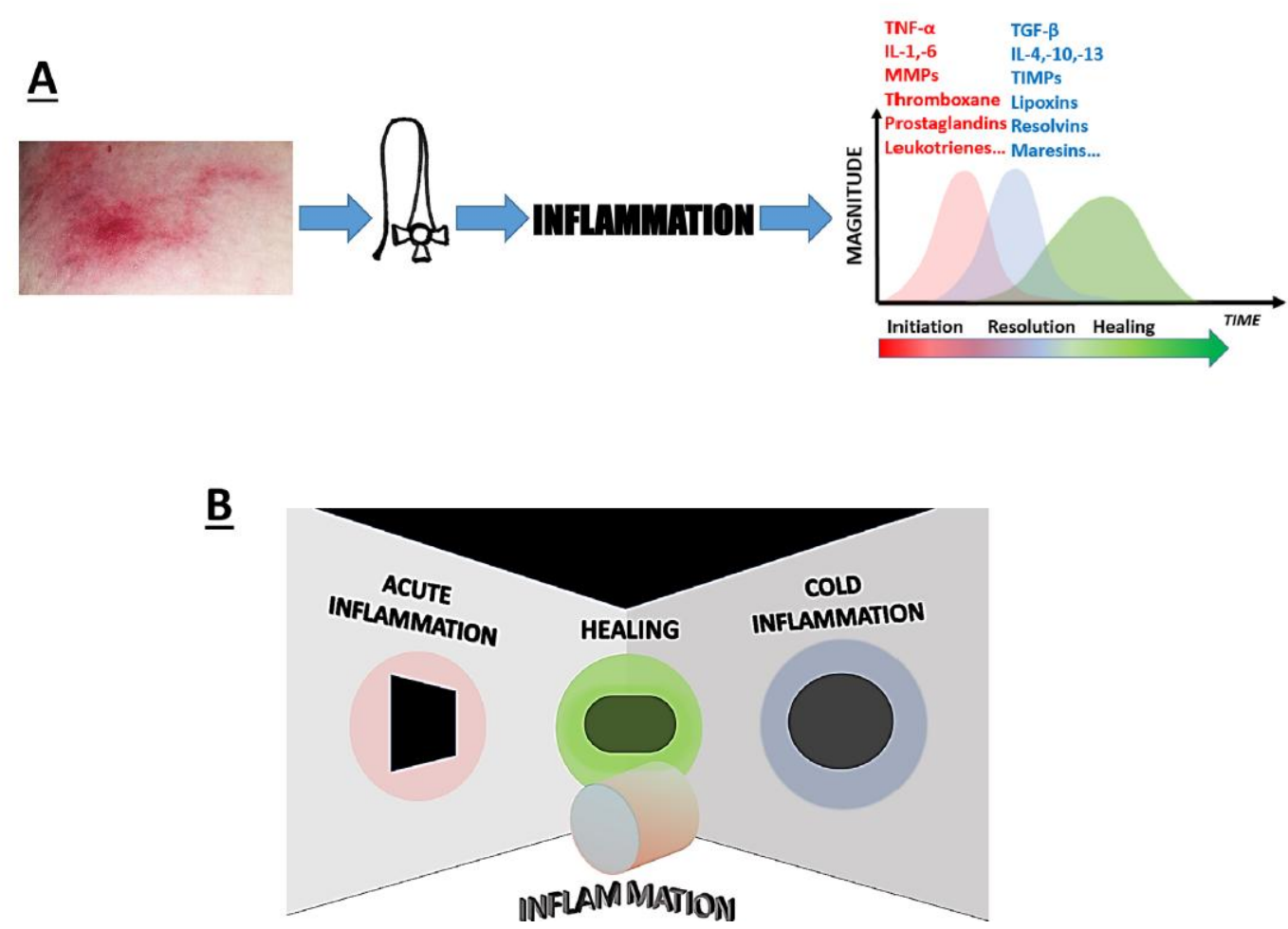

Figure 1. A) Symptoms, words and graphs are symbols. Symbols define (from Latin definire "to limit"). As such, they limit our mind. Hence, semiology is an essential part of our experimental approach. The hieroglyph reproduces a flaming brazier and was used around 1500 BC to symbolize inflammation.[3] B) Inflammation and the metaphor of the cylinder. Acute and resolving inflammation are two seemingly contrary processes that open the way to healing. Initially, inflammation was perceived through the symptoms of its acute phase i.e., "rubor" "calor," and "dolor." These early observations shaped the meaning of "inflammation." Thereafter, the so-called resolving phase, an active process mediated by pro-resolving mediators was discovered to be an integral part of inflammation. However, the epistemological obstacle carried on by the word "inflammation," together with our reductionist framework, contributed to dissociate the acute and resolving phases. The limits of our language becomes the limits of our mind. However, acute and resolving phases cannot be treated separately because they are connected together in a single entity. Inflammation emerges from this connection/reunification.

\section{Acknowledgements}

D.W. thanks Boudewijn van der Sanden and Andrew Moore for helpful comments and suggestions. This paper is dedicated to the memory of $\mathrm{Dr}$ Laurent Selek (1981-2017).

\section{Conflict of Interest}

The authors declare no conflict of interest. 
Received: June 1, 2018

Revised: June 11, 2018

Published online:

[1] L. W. Crafts, Recent Experiments in Psychology, McGraw-Hill, New York, NY, USA 1938.

[2] M. G. Netea, F. Balkwill, M. Chonchol, F. Cominelli, M. Y. Donath,

E. J. Giamarellos-Bourboulis, D. Golenbock, M. S. Gresnigt,

M. T. Heneka, H. M. Hoffman, R. Hotchkiss, L. A. B. Joosten,

D. L. Kastner, M. Korte, E. Latz, P. Libby, T. Mandrup-Poulsen,

A. Mantovani, K. H. G. Mills, K. L. Nowak, L. A. O'Neill, P. Pickkers,

T. van der Poll, P. M. Ridker, J. Schalkwijk, D. A. Schwartz,

B. Siegmund, C. J. Steer, H. Tilg, J. W. M. van der Meer, F. L. van de

Veerdonk, C. A. Dinarello, Nat. Immunol. 2017, 18, 826.

[3] G. Majno, The Healing Hand: Man and Wound in the Ancient World, Harvard University Press, Cambridge, MA, USA 1991.

[4] G. Bachelard, The Psychoanalysis of Fire, Beacon Press, London, UK 1964.

[5] D. Wion, F. Appaix, M. Burruss, F. F. Berger, B. B. van der Sanden, J. Biosci. 2015, 40, 657.

[6] M. Karin, H. Clevers, Nature 2016, 529, 307.

[7] C. N. Serhan, Nature 2014, 510, 92.

[8] C. D. Buckley, D. W. Gilroy, C. N. Serhan, Immunity 2014, 40, 315.

[9] H. F. Dvorak, N. Engl. J. Med. 1986, 31, 1650.

[10] M. L. Sulciner, C. N. Serhan, M. M. Gilligan, D. K. Mudge, J. Chang,

A. Gartung, K. A. Lehner, D. R. Bielenberg, B. Schmidt, J. Dalli,

E. R. Greene, Y. Gus-Brautbar, J. Piwowarski, T. Mammoto,

D. Zurakowski, M. Perretti, V. P. Sukhatme, A. Kaipainen,

M. W. Kieran, S. Huang, D. Panigrahy, J. Exp. Med. 2018, 215, 115.

www.advancedsciencenews.com www.bioessays-journal.com

BioEssays 2018, 18001031800103 (3 of 3) C 2018 WILEY Periodicals, Inc. 